\title{
Labour and the ecological crisis: The eco-modernist dilemma in western Marxism(s) (1970s-2000s)
}

\author{
Stefania Barca \\ Center for Social Studies, University of Coimbra, Portugal \\ Department of Environmental Studies, Faculty of Social Studies, Masaryk University, Brno, Czech Republic
}

\section{A R T I C L E I N F O}

\section{Keywords:}

Political ecology

Labour environmentalism

Western Europe

Production/reproduction

Raymond Williams

Laura Conti

André Gorz

Maria Mies

\begin{abstract}
A B S T R A C T
The article offers an intellectual critique of Marxist political ecology as developed in western Europe between the 1970s and 2000s, focusing on the labour/ecology nexus. My critique is based on the intersection of two levels of analysis: (1) the historical evolution of labour environmentalism, focusing on what I will call the eco-modernist dilemma of labour; (2) the meaning of class politics in relation to the politics of the environment, with a special focus on the production/reproduction dialectic. Focusing on the work of four Marxist intellectuals whose ideas resonated with various social movements across the Left spectrum (labour, environmentalism, feminism and degrowth), the article shows how the current entrenchment of labour within the politics of eco-modernization hides a number of internal fractures and alternative visions of ecology that need to be spelled out in order to open the terrain for a rethinking of ecological politics in class terms today.
\end{abstract}

\section{Introduction}

This article offers a critique of what I consider a major trend in the environmental politics of the neoliberal era in western Europe: the political convergence between labour and mainstream Ecological Modernization, what I will call labour's eco-modernism, and its contemporary divergence from anti-capitalist ecological movements. This pattern has become dominant in a historical context marked by a generalized decline in labour's representativeness and political power, both at the trade-unions level and at the level of an almost generalized electoral defeat of the radical Left (Ely, 2002; Ely and Nield, 2000; Silver, 2003; Van der Linden, 2008), as well as by a wide adoption of neoliberal policies in western European countries. At the same time, labour's eco-modernism hides important internal fractures and ecological contradictions: on the one hand, in the wake of increasing unemployment levels, a number of different sectoral unions and political parties on the Left continue to support fossil fuels and the opening of new extractive frontiers (from gold mining to fracking to coal itself); on the other hand, labour's endorsement of eco-modernism has been confronted by grassroots resistance against new 'clean energy' projects, such as, for example, wind farms and large-scale solar power plants, energy-from-waste facilities and high-speed railways. These divisions complicate immensely the effort to delineate a red-green agenda, or even to understand where the front is located in the current ecological class conflict.

Addressing this conundrum, I argue, requires us to develop (a critique of) the political ecology of labour, i.e. a material historical analysis of the internal relations between labour and ecology, focussing on the ecological significance of work and the political implications of workers' interaction with nature, both theoretically and in the historical praxis (Barca, 2014a; Ryle and Soper, 2016). My critique situates itself within the Marxist eco-feminist perspective on labour and workingclass agency. Adding to the notion of 'metabolic rift' as proposed by J.B. Foster $^{1}$ (2000; see also Foster et al., 2010; Clarck and York, 2005), Marxist eco-feminism focuses on 'the forces of reproduction', emphasizing the 'metabolic value' (Salleh, 2010) produced by forms of labour that lay beyond conventional (western) understandings of the term. According to Salleh (2010), 'metabolic value' indicates 'a subliminal "other" sphere of labour and value', that produced by the 'peasants, mothers, fishers and gatherers working with natural thermodynamic processes who meet everyday needs for the majority of people on earth' (Salleh, 2010: 205). Necessary to industrial production and exchange value, these workers - she writes - typically inhabit 'the margins of capitalism - domestic and geographic peripheries', and thus they are 'unspoken, as if “nowhere” in the world-system' (Salleh, 2012: 141). Naming them 'meta-industrial labour', while noting that they form the majority of the world's working class, is for Salleh an important way to make their work visible, and to value their contribution as 'rift-healing',

\footnotetext{
E-mail address: sbarca@ces.uc.pt.

${ }^{1}$ In his landmark Marx's Ecology (2000), J.B. recalled how - according to Marx - industrial capitalism has turned social metabolism into a 'metabolic rift', i.e. a process of accelerated degradation of both labour and non-human nature.
} 
i.e. contrasting the degradation of bodies and ecosystems put in motion by industrial production.

Salleh's concepts of meta-industrial labour and metabolic value build upon a material eco-feminist approach (Mellor, 2006; Perkins, 2007; Bauhardt, 2014), which aims to a re-conceptualization of political ecology via a socialist/feminist dialogue (Salleh, 2006). I find this approach extremely relevant to a re-conceptualization of labour environmentalism in both its historical and present forms. Seeing the labour/ecology nexus from the vantage point of Marxist eco-feminism, the crux of the matter for a critique of labour's political ecology becomes: what forms of work and what working subjects are included in labour's eco-modernism? and, more in general, what counts as labour in labour environmentalism? This perspective would allow us to broaden the scope of labour environmentalism by developing a decolonization of labour, both as concept and praxis, thus rendering visible its potentialities as an agent of ecological revolution.

Building on this approach, this article will develop a critique of labour's political ecology in western Europe in the last quarter of the 20th century. My intent is to reflect on the historical dialectical process by which western Marxism confronted the ecological crisis, focussing on how it conceptualised labour and working-class agency in respect to ecology. My argument is that, though becoming increasing aware of the constraints that prevented industrial labour from developing a proper response to the ecological crisis, European labour movements were incapable of developing a clear vision of the rift-healing agency of reproduction work (or meta-industrial labour) and of the need for uniting these two forms of labour subjectivity in a global solidarity alliance.

My narrative is built around the work of four public intellectuals Laura Conti, André Gorz, Raymond Williams, and Maria Mies - whose work represents different strands of western Marxism, and whose influence extended across various social movements not only in the respective countries, but also internationally. Reading these authors against the respective historico-political background, and confronting them with one another, I believe we can: (1) discern the conceptual trajectory through which the labour movement of western Europe came to embrace eco-modernism (2) understand how labour's eco-modernism is distinct from the capitalist version of Ecological Modernization; (3) develop a constructive critique of labour's ecomodernism from a materialist eco-feminist perspective. The next section will briefly delineate the current positioning of labour organizations within the contemporary political ecology scenario, and then introduce the research hypothesis and narrative that will be developed in the rest of the article.

\section{Labour in political ecology}

The first step for a critique of the political ecology of labour is that of defining labour and environmentalism as two composite fields of political action that are highly differentiated within themselves, and whose areas of intervention are overlapping in several ways. This approach in turn builds upon an understanding of nature (and the ecological crisis) not as a self-evident thing, but as a contested concept that crosses through labour and environmental fields, being conceptualized and acted upon in different ways within each.

That environmentalism has never been a homogeneous movement, and that different souls have co-existed within it is a key understanding in contemporary Political Ecology (Guha and Martínez Alier, 1997; Harvey, 1996). Two forms of environmentalism, Ecological Modernization (EM) and Environmental Justice (EJ), matter particularly in discussing labour environmentalism. The first, which now dominates environmental discourses in mainstream ENGOs and in global environmental politics (including climate negotiations), was originated as a North-European stream of social theory in the early 1990s (White et al., 2016). It offered an optimistic, win-win vision of environmental reformism as an effect of techno-fixes coupled with market incentives, which would come about as the result of a shift to post-materialist value systems in industrial economies. Like in most contemporary research on environmental politics, the 'post-materialist' concept was associated with a post-class, even post-political understanding of environmentalism. A highly contested theory, EM has nonetheless conquered center stage in environmental policy-making at various levels thanks to its perfect fit with neoliberal environmentality (Luke, 2011). As Maria Kaika has convincingly shown, EM has reached global dominance by being incorporated in the UN Sustainable Development Goals, where it has locked the debate on sustainability within 'the false dichotomy of market efficiency vs public accountability' (Kaika, 2017: 97). Even though its age of innocence is now over, after its complicity with 'new forms of displacement and "environmental/ecological gentrification" has been amply documented (Kaika, 2017: 91), EM now dominates the New Urban Agenda of the UN. This happens, according to Kaika, because the decision makers have chosen to ignore the voices of those urban communities and movements that are expressing dissenting, alternative visions of sustainability, geared on the praxis of 'commoning'. A similar argument has been made by Goodman and Salleh (2014) regarding the UNEP's official position on climate change.

On the opposite front, global EJ (or else, the 'environmentalism of the poor': see Martínez Alier, 2002) represents a subaltern and grassroots perspective which is gaining momentum in climate mobilizations, growing more self-conscious and poignant in identifying capitalism as the real culprit of the current ecological crisis - as in Naomi Klein's This Changes Everything, and in the climate justice movement more in general. The non-compatibility between this perspective and that of EM emerged with striking clarity at the Rio +20 Earth summit of 2012, where the official final declaration 'The future we want' - a univocal endorsement of Ecological Modernization via a 'green growth' agenda stood opposite to the alternative document approved by the Peoples' Summit, 'Another future is possible'. Seating at the official table and undersigning the UNCED declaration, the vast majority of labour organizations positioned themselves firmly within the first camp.

How should we make sense of this political positioning of labour with eco-modernism? According to Goodman and Salleh, the Rio Summit signalled the existence of a global counter-hegemonic bloc, formed of 'meta-industrial workers-urban women carers, rural subsistence dwellers, and indigenes' who represent the categories of workers hardest hit by the metabolic rift. These authors see the People Summit as an important step in the process of this global 'class' becoming self-aware of its political and ecological subjectivity. While largely agreeing with this vision, I believe we should not forget that the division between the EM and EJ blocs is internal to a broadly defined sustainability front, which stands opposite to the continuation of fossildriven economic growth (with the recent addition of new extractive frontiers in hydraulic fracturing, shale gas and rare earth materials) that characterizes the bulk of the world economy. Further, we need to consider that, like environmentalism, organized labour is not a homogeneous movement, thus the divisive line between sustainability and business-as-usual crosses through this camp as well. An emerging literature in Environmental Labour Studies (Räthzel and Uzzell, 2013; Felli, 2014; Cock, 2014) shows how the generalized adoption of a green growth/ecological modernization discourse on the part of many tradeunion confederations translates into little effective action because of the internal resistance coming from a number of sectoral unions, as well as contrasting signals coming from employers and governments (Burgmann, 2013; Snell and Fairbrother, 2013; Stevis, 2013; Sweeney, 2013).

Moreover, although international trade-unions confederations have aligned themselves with the hegemonic bloc, a number of workers' organizations (such as La Via Campesina, or the Landless Movement of Brazil) have positioned themselves with the counter-hegemonic bloc, and some unions do endorse an Environmental Justice or even an anticapitalist agenda (Murillo, 2013; Gingrich, 2013): the most common tendency in this case is that of adopting a social unionism approach, forming large coalitions with environmental and social justice 
organizations. Beyond all the difficulties typically confronting coalition building, however, these experiences face the opposition of even potentially progressive governments: this was the case in Spain, where a Climate Coalition (Coalición Clima) was founded in 2008 by 30 environmental NGOs, trade-unions, researchers, consumer organizations and coops, which put forward three draft bills (on mobility, energy and environmental taxing), all rejected by the then socialist government (Gil, 2013).

Moving from the global to the European scale, however, we can say that most labour organizations, represented by the European Trade Unions Confederation, are unequivocally aligning themselves with a 'green growth' bloc, advocating for a strategy of Just Transition based on public investments and tax incentives for creating blue-collar jobs in the 'clean energy', transport and construction sectors (ETUC, 2015). National initiatives such as the One Million Climate Jobs campaign in the UK (and more recently in Norway, Portugal, and France ${ }^{2}$ ) represent the most advanced version of this position, in the sense that they aim to overcome internal divisions within the labour front and build larger social coalitions to actively mobilize for the adoption of a green-jobs (or climate jobs) agenda. This strategic positioning has certainly to do with the fact that labour is currently facing the most serious and enduring economic crisis of the last decades, thus the green/climate jobs perspective appears as the one most likely to spur social and political consensus.

The problem with the Just Transition strategy, I have argued elsewhere, is that it is locking-up labour even more firmly with the continuation of capitalism and wage-labour in the 'green' mode - built upon the perpetuation of a gendered and racialized division of labour on the world scale - while ruling out a serious discussion of different perspectives and more radical alternatives, and thus the possibility to effectively eradicate the structural causes of both ecological and social inequalities (Barca, 2015). In this respect, labour's eco-modernism presents a striking similarity with the case of the New Urban Agenda highlighted by Kaika. In both cases, the endorsement of EM on the part of political and trade-union leaders rests upon a disregard for those dissenting voices and alternative praxes that locate themselves outside of (green) capitalism, claiming the social pre-eminence of reproduction, use value and the commons - in short, of meta-industrial labour. For a critique of labour's eco-modernism, the key questions then become: what alternate ideas and praxes were historically embedded in labour environmentalism? how did labour movements come to embrace Ecological Modernization?

To answer these questions, a good starting point is that of considering the intellectual roots of Marxist political ecology in western Europe, identifying the internal tensions and contradictions that derive from divergent readings of Marx and Engels, as much as from Marx's own work (Burkett, 1999; Foster, 2000; Clark, 2001; Moore, 2011). In this vast theoretical debate, I will single out here two points that seem particularly relevant to a critique of the political ecology of labour in western Europe. The first concerns the very notion of work in the (eco) socialist society: according to J.B. Foster, the Marxist tradition contains two different visions, one centred on the social potential of technology, scientific organization and automation, leading to the progressive reduction of working time and the increasing of leisure time; the other centres on the de-alienation of labour and the consequent liberation of its full potentialities for human development. To Foster, the second vision alone - which he traces to William Morris and to Marx - would be conducive to 'a genuine sustainable society' (Foster, 2017: 4). ${ }^{3} \mathrm{He}$

\footnotetext{
${ }^{2}$ See the official website of the OMCJ Campaign: https://globalclimatejobs.wordpress. $\mathrm{com} /$.

${ }^{3}$ The difference between the two visions lies in the value attributed to work: meaningless but necessary toil in the first case, potentially creative activity in the second. Clearly, such distinction can bear only in abstract terms, whereas in the historical experience of human beings the two forms of work coexist and complement each other; in fact, one could not exist without the other. So are the two forms of struggle: for those
}

criticizes the first vision, which he traces to the US writer Edward Bellamy, for 'taking production as economically and technologically determined' and focussing instead on leisure as a greater social end: a tendency that he sees represented today by the degrowth movement, via the influence of André Gorz.

The second point of the eco-Marxist debate that is of particular relevance here regards the idea, advanced by Foster and Clark in a previous essay, that European Marxists have been mainly influenced by the Frankfurt School's critique of the 'domination of nature', a philosophical anti-Enlightenment stance that, though grounded in writings from the early Marx, had 'led to the estrangement of thinkers in this tradition not only from the later Marx, but also from natural science-and hence nature itself' (Foster and Clark, 2016 ${ }^{4}$ ). According to the authors, this explains why western Marxism was ill equipped to respond to the rise of the environmental movement in the 1960s, and remained so until a 'second stage eco-socialism' arose in the late nineties, based on a new reading of ecology as a scientific concept inherent to Marx's thought.

In aiming to explain the convergence of labour movements with ecological modernization, this article departs from the above two points in various respects. Focussing on the last quarter of the 20th century, a period in which the influence of western Marxism on labour movements was still strong, although declining, I show how the distinction between the two visions of work highlighted by Foster had become increasingly blurred, being challenged by various inputs coming from the changing political and economic scenario. Central to these changes, I argue, was the question of political agency and subjectivity: in other words, the question of what role should the labour movement (and the working class in general) have in the ecological revolution. I locate Gorz's 'liberation from work' perspective within this political scenario, connecting it with contemporary political ecology visions developed in Italy and the UK. Regarding the second point, I show how the distinction between western Marxism and environmentalism was also quite blurred, as ecological concerns were being elaborated, in more or less direct reference to Marx, from within the labour movement itself. I will thus build an alternative narrative, seeking to trace the connections between labour and environmental concerns as they were being reformulated via a dialectical process that involved tensions and convergences between Marxism (o rather, various forms of western Marxism) and a variety of political movements across the Left spectrum, namely: labour, environmentalism (especially anti-nuclear movements), feminism, and degrowth.

The article's narrative goes as follows: by the mid-1970s, an early version of Marxist political ecology had taken shape in Italy, which found coherent expression in the work of the communist politician and intellectual Laura Conti (Section 2). Based on an understanding of ecology as the science of bio-physical interrelations, and on a vision of eco-socialism as science-based planning, this political ecology envisioned a strong urban/industrial working class as the only political subject capable of leading the rest of society towards the eco-socialist horizon. In this sense, it can be considered an early expression of labour's ecological modernism, which rested upon the progressive power of the productive forces, understood as male-blue collar workers in heavy industry and infrastructures. In the same years, a different political ecology perspective was coming from the Austrian-French intellectual André Gorz (Section 3): also based on a scientific

(footnote continued)

activities that are mainly painful or repetitive, and cannot be eliminated even in a disalienated social system, democratic control over technology and organization will be needed in order to reduce them to a minimum, to be carried out in the best possible conditions. All the remaining activities, in which creativity and realization of human potential can be achieved, will need to be socialized as much as possible, so that they do not remain a prerogative of certain social classes, and of one gender only.

${ }^{4}$ The quote is from the electronic version of the article, published in the Monthly Review Press with the title 'Marx's ecology and the Left'. See https://monthlyreview.org/ 2016/06/01/marxs-ecology-and-the-left/. 
understanding of ecology, this position differed from the previous in so far as it reflected contemporary discontentment with traditional ideas of working-class subjectivity and the ideology of work, while also breaking the nexus between the development of productive forces (or economic growth) and socialist ecological planning. In Gorz, the revolutionary ecological subject ceases to be the male blue-collar worker to become an undefined, multitude-like social subject who refuses to be identified on a class basis. This position reflected an incipient crisis of labour movements, consequent to a complex restructuring and tertiarization of labour markets in the core western European economies between the 1970s and 1980s. Together with the emergence of a strong green movement in those same countries, agglutinated by a common anti-nuclear stance (a position that labour movements were not ready to take), the eighties marked a divergence between labour and environmental movements, and the entrenchment of the former on the defence of economic growth at any cost. This increasing divergence and opposition formed the political trend to which a leading British Marxist intellectual like Raymond Williams felt the need to respond (Section 4), offering his own early Marxian (but also Polanyian) understanding of livelihood, or reproduction, as the common ground between labour and environmental concerns. Marking a definite departure from earlier visions of ecology as science-based planning, Williams exhorted the labour movement to move away from the production ideology that had held it hostage of the development of capitalist productive forces. Unlike Gorz, however, he maintained that the political subject for the ecological revolution could only be the labour movement - once this had elaborated the necessary 'qualitative alteration of socialism'.

Summing up the narrative so far: while Conti's eco-socialism was to be built at the point of production, Gorz and Williams pointed towards reproduction (or livelihood) as the terrain where a different political ecology of labour could have been built. For this to become a hegemonic vision of labour environmentalism, however, something was missing: reproduction needed to be more clearly theorized as the bearer of political agency and subjectivity. This was a step that the feminist movement had taken in the previous decade, without being able to carry out the necessary triangulation with labour and environmentalism. The German scholar/activist Maria Mies exemplifies this point (Section 5): moving from a critique of the colonial and sexual divisions of labour that underlie capitalist accumulation, Mies had elaborated a rethinking of the labour/ecology nexus based on the social centrality of reproductive work. These ideas, developed in a period of great turmoil for European socialism due to the fall of the Soviet bloc, were foundational for the development of material eco-feminist thought, but did not influence the evolution of labour environmentalism. By the turn of the 20th century, in fact, most of tradeunion organizations and Left parties in western Europe had steered away from eco-socialism and were officially embracing the mainstream Ecological Modernization perspective. The disconnect between labour and eco-feminist movements, I argue in the conclusions (Section 6), prevented the former from completing the 'qualitative alteration of socialism' that it needed to address the ecological crisis on its own terms, without succumbing to the logic of green capitalism. Opening to the material eco-feminist understanding of work and political subjectivity might have led western labour movements towards a convergence with the global Environmental Justice perspective, instead.

The next section identifies Italy as the place where an early political ecology of labour took shape from within the Marxist tradition in the mid-seventies, and then evolved into a mass social movement, rescinding its original nexus with the labour movement a decade later.

\section{The 'ecology of class'. Laura Conti and the Italian Left}

Since the early seventies, the thesis of ecological crisis as a contradiction of capitalism had appeared in Italy via what was then the biggest communist party in western Europe, the PCI. During its 1971 cadres' school in Frattocchie (notably, one year before the ecological crisis was officially declared by the Club of Rome), the PCI had held its first national meeting on the theme "Man (sic), nature, society," where party executive Giovanni Berlinguer ${ }^{5}$ had admitted the need to update Marxist orthodoxy in order to take into account the concept of natural limits. He had compared ecology to socialist planning and emphasized the need for the party to consider the environment a working-class priority (Graf Von Hardenberg and Pelizzari, 2008). A few years later, the public intellectual and PCI representative Laura Conti published her Che cos'é l'ecologia. Capitale, lavoro, ambiente [What is ecology. Capital, labour and the environment] (1977), a book which offered a theorization of this new vision and the elaboration of a corresponding political strategy. A physician by training, and a passionate science writer, Conti became a leading figure in the birth of an Italian left-green movement (Barca, 2014b). She defined political ecology as the study of how social relationships within the human species influence the natural world and other species, and described ecology as a metabolic relationship between society and the environment. The key thesis in the book was that such complex web of interrelationships between natural and social mechanisms needed a good dose of environmental planning, to be democratically designed and governed. The struggle against those who damage nature, "the life of our and other species," Conti wrote, could not be left in the hands of the market or some eco-technocracy, but must have society as a protagonist, and specifically one social class: the one that opposed capital. In defending not only its own interests, but those of humanity itself as belonging to the sphere of nature, the working class would find substantial solidarities and coalitions in society - Conti believed.

The relationship of labour with environmental movements was a rather marginal topic in Conti's approach: she took note in passing of the antipathy between (industrial) workers and environmentalists, but this to her simply represented a healthy reaction of the working classes towards a certain type of (middle-class) environmentalism based on moralistic condemnations of mass consumption and on the defence of some charismatic mammal (Conti, 1977: 140n). Instead than on an unlikely alliance with this kind of environmentalism, Conti's political ecology was philosophically grounded on Marx's concept of alienation from species-being. For her, this pointed to the need for labour organizations to develop their own ecological revolutionary reformism, i.e. an 'ecology of class', in order to counter capitalism's abuse of the environment from within (Conti, 1977: 136-39).

The 'ecology of class', however, was ridden by an apparently irreducible internal contradiction, of which Conti was critically aware, what I would call the eco-modernist dilemma of labour: the advancement of a working class ecological consciousness was consequential to the development of the forces of production, in the sense that only an advanced industrial apparatus could grant the occupational levels and political strength that were necessary for workers to develop their role as defenders of the environment. In Conti's vision, labour environmentalism had to work with this contradiction: she thought that a possible response was for the Left to push towards the development of those industrial sectors that granted the higher occupational level with the lower relative environmental impact. Even though only limited and temporary solutions such as this could be found, she noted, this was a struggle that the labour movement could not postpone.

Conti's response to the ecological crisis was somehow representative of the 'official' line adopted by the communist party in this respect - or at least, that which was most acceptable within the eurocommunist politics of the late 1970s and early 1980s: rather than rejecting industrial modernity in its entirety, the communists had to exercise their power within and outside the Italian parliament for keeping the

\footnotetext{
${ }^{5}$ Giovanni was the younger brother of Enrico Berlinguer, who became PCI's secretary general in 1972. A physician by training, he was the author of numerous works on the history of medicine, and became a reference for Marxist occupational health science in and beyond Italy.
} 
destructive power of the forces of production at bay, via democratic control. This democratization of production started at the workplace, where a new methodology of participative workers' control had been elaborated in a collaboration between the confederate unions and a handful of militant scientists, and reached society at large via public institutions which the workers' movement was struggling for painstakingly in those same years, such as the national public health system (Barca, 2012).

The 'ecology of class' approach, however, presented other limitations, both internal and external. To begin with, the strategy of workers' control over industrial toxicity via trade-unions and public institutions was highly vulnerable to cycles of economic recession, especially in industrial production, which restricted the possibilities for capital to invest in health and safety measures and impaired the negotiating power of unions in the workplace. The strategy was also blind to geographical, sectoral and gender differentiations within the Italian working class: it not only proved unsuccessful in the 'underdeveloped' South, but it also reinforced an implicit acceptance of male blue-collar work in heavy industry as the only meaningful form of political mobilization in an area of social policy - that of environmental and public health - which entailed much broader significance and subjectivities.

Nevertheless, this approach did produce important results in terms of convergence between red and green politics, among which the founding of the Italian League for the Environment (Legambiente), today a well-established Italian ENGO, created in 1979 as a sub-section of the PCI recreational branch. Conti played a leading role in the foundation of the new organization, together with a handful of public intellectuals who shared a common militancy in the PCI. ${ }^{6}$

During the 1980s and 1990s, the 'ecology of class' strategy was thoroughly challenged by the changing structure of the Italian economy, with the tertiarization and then precarization of the labour force, and environmental concerns gradually shifted from the point of production to that of consumption (Della Seta, 2000; Della Porta and Diani, 2004). Consequently, Legambiente started to detach itself from the PCI by refusing centralized strategies and promoting instead forms of territorial organizing 'outside the workplace, and away from any logic of economic defence" (Della Seta, 2000: 50-51). The definite detachment came in 1986, together with a choice for privileged relationships with the Green party in local and national elections. The crisis of the 'ecology of class' approach became clear when the Left (the communist and socialist parties and the CGIL union) split along two opposite fronts facing the anti-nuclear referendum promoted by the Greens and environmental organizations in 1987 (Della Seta, 2000).

Legambiente's move from the factory to the territory thus reflected a process of historical division within the Italian Left, more than between labour and environmental organizations, a division that became more evident with the split of the PCI into two political formations in 1991. This coincided with a marked shift in the eco-Marxist debate, that found expression in the magazine Ecologia Politica - Capitalismo Natura Socialismo, ${ }^{8}$ founded in 1991. The magazine introduced the thesis of ecological crisis as capital's 'second contradiction', put forth by US scholar James O'Connor in his introduction to the first issue of CNS (O'Connor, 1988), ${ }^{9}$ while also popularizing different versions of radical

\footnotetext{
${ }^{6}$ Among them, the urban ecologist Virginio Bettini, who had co-authored with Barry Commoner a book called Ecologia e lotte sociali. Ambiente, popolazione, inquinamento [Ecology and social struggles. Environment, population, pollution] (1976), putting forth the thesis of the two ecologies (ecology of power and ecology of class), which became a political manifesto for the Italian left ecology. Yet another founding member of Legambiente was the chemist Giorgio Nebbia, also a well-known academic and the author of a number of books and pamphlets on political ecology (see Barca, 2014b).

7 The claim is attributed to Andrea Poggio, journalist and author, one of the founders of Legambiente and director of the magazine La Nuova Ecologia between 1980 and 1984.

${ }^{8}$ The magazine, a sister publication within the international family of western ecoMarxism - namely, in connection with the US based Capitalism Nature Socialism, the French Écologie et Politique, and the Spanish Ecología Política, was directed by Giovanna Ricoveri and Valentino Parlato (who was also the director of the newspaper Il Manifesto).
}

ecological thinking. ${ }^{10}$

In short: rather than representing a shift from the materialist to the post-materialist approach to environmentalism - where materialism is reductively intended as 'economic defence' - Italian political ecologists expressed a more specific shift: from the political hegemony of the PCI, geared on the ideological hegemony of the urban industrial proletariat, to a grassroots, territorial perspective on ecology, where a diversity of social subjectivities were to be aggregated towards the defence of the conditions of production against industrial toxicity. This shift, however, came after the concept itself of working class had been subjected to a radical political-ecology critique. Let us now turn to examine that critique.

\section{Farewell to working-class ecology. André Gorz and the 'liberation from work'}

In 1977, the same year in which Conti's What is Ecology came out in Italy, the notion of the ecological crisis being a political issue of special relevance for socialism was being raised, on radically different grounds, by Austrian-French intellectual André Gorz in his essay Ecology and Freedom (Gorz et al., 1979), first published in France as Écologie et Liberté (1977). Inspired by a kind of humanist socialism deriving from a variety of non-orthodox Marxist influences (from Sartre's existentialism and Marcuse's critique of domination, to the May 1968 students' movement and the Italian so-called autonomous Marxism), Gorz introduced the theme of nature as an external limit to growth and defined political ecology as the struggle for a democratic and emancipatory politics of the environment. The essay presented the ecological crisis as a crisis of reproduction by overaccumulation, and exposed the risks of economic reductivism deriving to labour from an uncritical adoption of the productivist ethos - a thesis he developed in full length in his later Critique of Economic Reason (Gorz, 1989) [Métamorphoses du travail, 1988]. Gorz's political ecology was thus intended not only as a critique of the capitalist mode of production, but also as an instrument of liberation from the conceptual categories that constrained the labour movement within the capitalist order: a political project 'capable of, at the same time, overcoming capitalism and transforming socialism itself' (Leonardi et al., 2015: 17). Also in later writings, he maintained a constant effort at dialoguing with various labour organizations, and with trade-unions in particular, inviting them to challenge the 'ideology of work' (Gorz, 1999).

Gorz did not see the overcoming of capitalist industrialism as a return to the pre-industrial order of medieval craftsmanship and village economy. Rather, he developed a socialist utopia where people regained control over industrial technology, not via centralized forms of state planning but via individual and community self-management. If ecology was not compatible with capitalist rationality, it was not compatible with authoritarian socialism either. Moreover, like ecology, so technology was not socially neutral: only those technologies that were compatible with capitalism (or, with State socialism) in their drive for the quantitative growth of production - regardless of qualitative considerations - had been developed thus far. The clearest example being that of nuclear power, presupposing a de facto authoritarian social order. Consequently, the strive for a different society passed through the struggle for different technologies: 'socialism is no better

\footnotetext{
${ }^{9}$ The article postulated that the point of departure of ecological socialism was the contradiction between capitalist forces and relations of production and the 'conditions of production', which he viewed - following Polanyi - as 'fictitious commodities'. This contradiction would cause ecological crisis as a 'crisis of underproduction', i.e. a nonMalthusian version of scarcity, whereby capital induces the destruction of the conditions of production. This kind of scarcity, O'Connor believed, would lead to an increased socialization of production, via economic planning and environmental regulations, thus creating the possibility for an ecological path to socialism.

${ }^{10}$ Examples are Mumford's critique of technology, or Sachs' and Latouche's critique of western development. For a (partial) list of articles published in the 1990s, see: http:// www.ecologiapolitica.org/wordpress/?page_id $=1245$.
} 
than capitalism if it does not change tools', he stated (Gorz, 2010: 9). Only those technologies that could be controlled at the community scale, bring about greater individual or local autonomy, preserve the reproduction of life, and facilitate producers and consumers' control should be developed (Gorz et al., 1979).

Gorz's political ecology was an intellectual's call to the labour movement for the transformation of socialism. A much greater impact, however, had Gorz's by far most popular book, Farewell to the Working Class, significantly sub-titled An essay on post-industrial socialism (Gorz, 1982), first published in France as Adieux au Prolétariat (1980) and two years later translated into English and Italian. The book presented the thesis that the time had come for the labour movement to emancipate itself from the ideology (and ethic) of work-as-employment, and move towards a post-industrial revolution which fully acknowledged the new historical subject formed by the 'non-class of post-industrial proletarians' (Gorz, 1982: 66). Published on the verge of de-industrialization and post-Fordist restructuring of production in western Europe, the book envisioned the end of the age of full employment and Keynesian welfare, to be replaced by a society of 'freed time' based on the autonomous production of use-value - a thesis that sounded then fresh and timely. The core idea it presented was, however, very old and even foundational to Marxian thought: 'Communism is neither full employment nor a wage for everyone - Gorz wrote - but the elimination of work in the socially and historically specific form it has in capitalism. That is to say, it is the elimination of work-as-employment, work-ascommodity' (Gorz, 2010: 11). This was a mostly forgotten dimension of Marxist thought that Gorz had derived from non-orthodox Marxists such as the East German Rudolf Bahro and the Italian Antonio Negri (Gorz, 1982: 88).

The key point in the book was that capitalism would not end by its own internal contradictions, nor by reaching its external limits namely, the ecological. On the contrary, he wrote, in the past twenty years capitalism had demonstrated an unexpected ability 'to manage the non-resolution of its problems, accommodate its dysfunctions, even drawing renewed strength from this state of affairs'. Furthermore, such problems would remain unresolved even if the working class took control over the forces of production - that is, without changing them qualitatively. The sad news, in fact, was that capitalism had produced a working class whose immediate interests were more consonant with the reproduction of capitalism itself than with 'a socialist rationality'. Consequently, the eradication of capitalism could only come from those areas of society that embodied or prefigured 'the dissolution of all social classes, including the working class itself' (Gorz, 1982: 14-15). Gorz's suggestion was not that of replacing the traditional Marxist working class with a different but equally transcendent subject, a new class with a new mission of historical salvation. Like all nascent social movements, he wrote, that of 'those who refuse to be nothing but workers' was a non-class with a strong liberation ethic, 'a negation of law and order, power and authority, in the name of the inalienable right to control one's life' (Gorz, 1982 11). The movement was thus not structured as such, because its main concern was the building of individuals' autonomy. This was, at the same time, its main strength and weakness, because spaces of autonomy captured from the existing social order will be marginalized, subordinated or ghettoized unless there is a full transformation and reconstruction of society' (Gorz, 1982: 12).

As Martin Ryle and Kate Soper have noted, André Gorz gave voice to an alternative, radical thought on ecology and labour that was emerging between the 1970s and 1980s, one which posited a new connection 'between the human desirability of a less work-dominated life and the environmental necessity of a less indiscriminately productivist economy' (Ryle and Soper, 2016: 120). In Gorz's Écologie et liberté, and in some intellectual circles in France, this idea started to be called decroissance (degrowth), a concept that has received increasing attention in the wake of the current economic crisis, especially in southern Europe. ${ }^{11}$ This renewed interest has given birth to what now considers itself as an umbrella movement - a convergence of social movements and intellectuals that strive for decoupling social welfare and the good life from the imperative of economic growth (D'Alisa et al., 2014). Gorz's ideas on the 'liberation from work' are central to today's degrowth movement. Needless to say, however, the demise of the Fordist organization of work and the abandonment of a working-class centred politics have not resulted in the desired 'liberation from work' - quite the opposite, one could say. There was in Gorz no further elaboration on which alternative possibilities could be developed in replacement of the old class perspective, nor a critical analysis of the 'new social movements' that had occupied the scene of ecological activism, mostly via anti-nuclear mobilization, evolving into new political formations the green parties.

To sum up: Gorz gave voice to a diffused disillusionment with the opportunity, and even the possibility to develop an 'ecology of class' strategy, based on the political subjectivity of the labour movement. This disillusionment located itself within a historical phase of post-industrial transition experienced by France, Italy, Germany and most of western Europe in the 1980s, which, coupled with an almost generalized shift to neo-liberal policies of 'flexibilization' of work and welfare cuts, contributed to a serious weakening and crisis of the labour movement. At the same time, the post-industrial transition seemed to open the way to a 'liberation from work', or 'refusal of work', as theorized in the Italian workerist/Autonomia movement: a position that was radically alternative to, and also vehemently opposed by, the traditional labour movement.

The crisis of the 'ecology of class' approach signalled a situation in which political ecology could not be seen any longer as a territory hegemonized by the labour movement: the environmental movement was consolidating itself as a 'new social movement' grown out of radical, grassroots mass mobilizations against nuclear power all over western Europe (Rootes, 2003), so that it was not possible for Marxists and the traditional Left to depict it as an expression of elitist concerns with charismatic wildlife, as Conti had done before. In other words, the eighties were a time when it became evident that a red-green politics needed to be built upon a new relationship between labour and environmental movements. The next section will thus illustrate how this possible alliance was envisioned by one of the most prominent Marxist intellectuals of the time: the British critic Raymond Williams.

\section{4. 'A qualitative alteration of socialism': Raymond Williams on labour and ecology}

In June of 1984 Williams was invited by the Socialist Environment \& Resources Association of Letchworth, UK, to deliver a speech on 'Ecology \& the Labour Movement'. He started with the claim that: 'No political development is now more necessary than a convergence between the ecology movement and the labour movement' (Williams, 1984). ${ }^{12}$ Offering a compelling narrative of how work and nature related to each other under industrial capitalism, he envisioned a possible convergence between labour and environmental movements, based on two prerequisites: first, that labour be willing to replace the notion of 'production' with that of 'livelihood'; second, that the environmental movement recognized capitalism as the enemy of nature.

Williams characterized eco-socialist politics in the following terms: the ecological crisis was a product not of modernity in itself - intended as the ability to feed more people out of a limited amount of resources, the ability to escape the Malthusian trap - but of capitalist modernity. The latter was to be understood as a mode of production in which both labour and the environment were considered 'raw material' (or

\footnotetext{
${ }^{11}$ On reduction of working time and degrowth see for example Giorgos Kallis, In defence of degrowth. Opinions and manifesto, edited by Aaron Vansintjan (indefenseofdegrowth.org), esp. chapters 14 and 15.

${ }^{12} \mathrm{~A}$ video recording of the speech is now available at https://www.youtube.com/ watch? $\mathrm{v}=$ EiFWHtKOcj0. I wish to thank Jason W. Moore for posting this resource on the World Ecology Research Network, through which I came to know about it.
} 
'resources') for accumulation and profit, rather than an end in themselves. The point for the labour movement was to change that system, not to run it more efficiently. William's political ecology converged with Gorz's in rejecting a vision of systemic change that implied a return to pre-industrial agriculture and craftsmanship - he rejected the idea that these modes of production would be able to maintain the current levels of population in Britain. A non-capitalist modernity seems to be the horizon towards which he thought ecology and labour could merge.

In William's account, the (UK) labour movement had emerged from a specific environment, that of the first industrial revolution, characterized by the enclosure of common lands, and consequent essential changes in food production and livelihoods; and new ways of 'drawing power from nature' related to the coal-and-iron technology. All this gave society an unprecedented capacity to transform nature, a transformation which became a common work experience. 'Out of that chaotic and dynamic experience, a labour movement was formed, which was primarily defensive', he noted, for it formed around the notion of remediable poverty. And the answer to poverty that was on offer by the social order - he noted - was: 'produce more and you will no longer be poor - work harder'. Socialists soon realized that there is no necessary correlation between increased production and the reduction of poverty, because the social relationships set up in the course of production, determine in large part the decisions about how the surplus is distributed. This makes the possibility for great poverty to continue amidst great wealth - if this is functional to the social order. Thus the problem was not production per se, said Williams, but the relations of production. For the majority of its history, he claimed, the labour movement had not taken this difference seriously.

The problem Williams was pointing to was labour's entrenchment within the dominant instrumental rationality of capitalist modernity, which labour, he seemed to say, had accepted as an ineluctable fact of life. However, he noted, with the evolution of industrial capitalism, raw materials had become redundant, and population had reached a point much higher than the demand for labour, so that people had become redundant as well, like a raw material that could be left in the ground. And at this point, Williams claimed, the labour movement faced its greatest crisis, a crisis of ideas:

because, if it continues to see more production as the way to fight poverty, it is simply going to produce its own general redundancy. It is a process which has a certain iron law about it... So the battle now is... whether you will continue to accept the predominant mode of production ... or whether you can (and this is where the convergence with the ecology movement must happen) begin to think of a different social order.

The time had come, in other words, to recognize that the problematic relationship of labour with ecology derived from the passive acceptance of this misleading habit of thought, by which production was the necessary and sufficient answer to poverty, while wage labour and private property had become undisputed social institutions. Breaking through this political direction implied abandoning the idea that socialism could compete with capitalism in running the same system better, i.e. 'producing more', because the long-term consequences of this model on people and the environment had become unmistakeably clear.

What was the alternative to that? To 'challenge the notion of production as it has been presented, and start with a different conception' Williams stated - one around which the convergence between the socialist and ecology movements could take place, i.e. the idea of livelihood. Livelihood was to Williams 'a much deeper concept, and much more human concept than production', because the latter was 'nearly always a gross quantity, indiscriminate as to what you produce, what quality you produce, what effects that production has on others and other kinds', and this prevented the system from prioritizing real human needs. On the contrary, livelihood meant 'starting from human place, and from the interest of all living beings involved'.

William's formulation of the relationship between ecology and labour in terms if livelihood seems consistent with O'Connor's theory of ecological Marxism, formulated a few years later (O'Connor, 1988), and signals a tendency of Marxist political ecologists towards converging with the polanyian critique of commodification that was becoming popular in Leftist circles of the time. The originality of Williams' approach, however, consisted in wondering how could livelihood be sustainable in a modern, industrial economy: this was, to him, the core dilemma in the relationship between ecology and labour.

The answer that the environmental movement had given was not satisfactory, he claimed, and that was the main reason why the labour movement needed to step in and take the matter in its hands. While questioning the priorities of the production system, in fact, the environmental movement had done so by calling the system soft names industrial society or modern society - and thus it had never got to 'the hard political choices'. If environmentalists could get to the point where they identified capitalism as the enemy of nature, and if - at the same time - the labour movement were prepared to move in the same direction, then a common basis for red-green politics could be found. If that conversation succeeded, it would produce not simply a convergence between two movements, he concluded, but 'a qualitative alteration of socialism'. And the only force which could carry through this transformation was 'the force which is rooted in the majority interest and in the indispensable livelihood of all the people in the society, and that... ideally... is the labour movement' (O'Connor, 1988).

To sum up: Williams shared Conti's idea that a strong labour movement is the social subject capable of leading an ecological revolution, but, like Gorz, he did not consider this as a necessary and natural political choice for the labour movement, at least not until a convergence had been realized between this and the environmental movement on the terrain of a politics of livelihood. While all three shared a Marxist critique of capitalism's ecological contradictions, they lacked an understanding of coloniality/racism and patriarchy/sexism as fundamentally constitutive of industrial capitalism itself (and, to a large extent, of then existing State socialism as well), and thus of the capitalist world-ecology (Moore, 2011). Such awareness was being produced by the ecological strand of the feminist movement, to which the next section is dedicated.

\section{Redefining labour. Maria Mies and the materialist eco-feminist approach}

Since the early 1970s, a much-needed reflection on domestic and reproduction work as a crucial 'hidden abode' of capitalism had emerged in Italy, France, Germany and other western countries (Arruzza, 2016; Dalla Costa, 2015; Fraser, 2014), contributing in fundamental ways to de-structuring old conceptions of work centred on the industrial workforce and on waged employment in general. What is less well known is the fact that this reflection allowed a number of scholars and activists to also develop a materialist eco-feminist perspective based on a critique of the sexual division of labour on the global scale. Probably the most important contribution in this respect came from the German academic and long-time feminist Maria Mies, whose Patriarchy and Accumulation on the World Scale, first published in Germany in 1986, soon became a key reference in material eco-feminism (Mies, 1996). The relevance of the book to a discussion of labour and ecology should not be underestimated. It pointed to the same problem that Williams had identified in his Letchworth speech, that of abandoning a reductive understanding of production as the only terrain where poverty could be addressed - but it did so by adding two perspectives that were utterly absent from Williams (as well as in Conti and Gorz): that of women's hidden work and that of the international division of labour. The book focused on what Mies called 'the general production of life, or subsistence production', which she saw as 'mainly performed through the non-wage labour of women and other non-wage labourers as slaves, 
contract workers and peasants in the colonies' and that for her constituted 'the perennial basis upon which "capitalist productive labour" can be built up and exploited.'

The book added a fresh perspective on the sexual division of labour, theorizing it as an issue that went beyond the family sphere, and that defined an entire social structure, including both class relationships and social relations with nature. In a decisively non-essentialist fashion, Mies explained men/women differentiations as evolved out of a historical process, thus criticizing the naturalization of (women's) reproductive labour in Marx and Engels, for whom reproductive activities 'do not belong to the realm of 'productive forces', of 'labour', 'industry and exchange* but to 'nature' (Mies, 1994: 52). 'By separating the production of new life from the production of the daily requirements through labour, by elevating the latter to the realm of history and humanity and by calling the first 'natural', the second 'social' - she wrote - they have involuntarily contributed to the biological determinism which we still suffer today. With regard to women and their labour, they remain as idealistic as the German ideologues whom they criticized' (Mies, 1994: 53). To Mies, Marx and Engels' vision ultimately reflected the historical process by which the patriarchal order had been incorporated by European feudalism first (via the witch hunt) and then by industrial capitalism, when 'the sphere where labour power was reproduced, the house and the family' was redefined as 'private, domesticated nature', while the factory was defined as 'the place for public, social ('human') production' (Mies, 1994: 69). Even though this distinction belongs more fully to the housewifization process of the Fordist period than to the early industrial era - when a great number of factory workers were women - it remains of great relevance in understanding the social subordination of women as typically non-political subjects, and of reproduction as a non-political terrain of social life.

In the following two decades, Mies gave path-breaking contributions to the global eco-feminist literature with the books Ecofeminism (Mies and Shiva, 1993) and The Subsistence Perspective (Mies and Bennholdt-Thomsen, 2000), which established strong connections between ecology, feminism and the emerging anti-globalization (or alterglobalization) movement. They contributed substantially to the discussion of work beyond wage-labour and the urban-industrial proletariat, and showed how the possibility for developing a 'good life' beyond capitalist growth was already practiced in a number of rural and third world contexts. Emerged from within a scholarly/activist group in 'women and development' studies across Germany, Austria and the Netherlands (Mies, 2006), the 'subsistence perspective' was thus an empowering concept that gave value to people's abilities to cooperate with each other and with nature in the 'production of life'.

Mies' work resonated with that conducted in the same period by Italian autonomous-Marxist feminists Silvia Federici and M. Rosa Dalla Costa, and by the British eco-socialist scholar and activist Mary Mellor (Dalla Costa, 2003; Federici, 2012; Mellor, 1999). What these arguments had in common was their going beyond the traditional, typically male-dominated national labour movements, to look at exploitation and solidarities at the world scale, where the majority of working-class people were rural third-world women (Salleh, 2010). The global/sexual division of labour was thus the level at which these authors and activists, many of whom came from a Marxist-feminist background, developed an ecological critique of capitalism from the point of view of reproduction and livelihood (Salleh, 2006). This intellectual/activist work has been built through a materialist approach to both ecology and feminism, but also in a transnational conversation that intersected in important ways with post-colonial and third-world studies, while operating a difficult dialogue between constructivist and realist approaches to 'nature' (Soper, 1995). The common analytical terrain was that of exposing the material effects of the capitalist/patriarchal/colonial order in terms of depletion of both ecosystems and people, via extraction of unpaid labour from (mostly women) reproducers and from nature, which originated in the cultural depreciation of reproductive services, while leading to their commodification.
Eco-feminist political economy is of fundamental importance to a consideration of ecology and labour in so far as it exposes the dangers of western cultural dualisms (between 'culture' as mind-agency-production-masculine and 'nature' as body-passivity-reproduction-feminine) that are deeply enmeshed within socialist politics as well. Its central concern is the need for thoroughly revisiting the notion of what counts as 'labour'. However, the materialist eco-feminist debate took place mostly in 'global' places such as the first Rio earth summit, or 'women and development' conferences (Merchant, 2005; Salleh, 1997), crucially involving women scholars and activists working in the global south; additionally, most eco-feminist scholars and activists developed their work outside Europe. As a consequence, the impact of this debate on the development of a red-green political agenda in the old continent was very limited, if not absent. The material eco-feminist perspective was born and developed as an outsider to the traditional labour movement, and has remained so to this day. Marginalized, and also misunderstood by so-called third-wave white feminism (Gaard, 2011), it has gained new momentum in the last few years thanks to a materialist turn in gender studies, but also thanks to the growing mobilizations of Indigenous, peasant, and other racialized women against the increasing commodification and depletion of life in the new millennium.

\section{Conclusions}

The last three decades of the 20th century have represented a crucial turning point in labour environmentalism. The approach that had been consolidated in the Fordist era, based on trade-unions' struggles for health-and-safety regulations at the point of production, extending to society at large via democratic planning - what Italian communists called 'the ecology of class' - lost its centrality, and a variety of different visions emerged on the European Left. None of them, however, succeeded in preventing the labour movements of western Europe from losing their anti-capitalist perspective and from embracing an ecomodernist political ecology. This defeat should be read against the historical background of structural and political constraints (economic stagnation, de-industrialization, and the end of the soviet experience); however, it must be also explained as the effect of internal shortcomings of Marxist political ecology: namely, the disconnect between eco-socialist and eco-feminist visions.

At the time of writing, the prospects for a red-green politics in Europe seem to be now polarized around two blocs, which could be seen as broadly representative of, respectively, Ecological Modernization and Environmental Justice: the first bloc revolves around a labour-friendly green growth plan based on a mix of market and non-market regulation, as represented by the ETUC and the socialdemocrat group at the European Parliament; the second bloc is inspired by a post-development and global environmental justice vision, as represented by the degrowth movement, towards which the materialist eco-feminist perspective has converged, and which also incorporates a reclaiming of the 'common' as the political terrain for (ecological) anticapitalist politics.

The first option represents the official position of labour environmentalism: however, this is now understood in a quite different way than its eco-socialist version. The JT and climate jobs strategies, in fact, see workers not as the political subject of an ecological revolution, but as potential victims of climate policies. In other words, whereas the ecology of class was a transformative strategy, oriented towards a classbased defence of reproduction, this new version of labour's eco-modernism is a conservative strategy, built around the defence of production. The second option, on the other hand, manifests in grassroots resistance to both carbon-intensive activities and 'clean energy' megaprojects, as well as in a number of urban squatting/gardening/worksharing initiatives, many of which are consciously adopting degrowth principles. According to degrowth advocate and scholar Giorgos Kallis, these actions are not inspired by an escapist, but rather by a nowtopia 
attitude, i.e. one that aims at changing the city by linking grassroots with institutional action. ${ }^{13}$ It must be noted, however, that this strategy has failed so far to gain mass traction with the impoverished and precarized working classes of the austerity era, nor seems it capable of having a constructive dialogue with the labour movement in general.

The disconnect and even occasional hostility between an eco-feminist perspective, now strictly allied with environmental justice/postdevelopment/degrowth movements, and labour's eco-modernism is what is currently impairing the possibility of developing a stronger and more convincing anti-capitalist ecological struggle, both in Europe and at the global level. This strategy, I contend, should aim at transforming labour environmentalism into an antipatriarchal and anticolonial alliance between industrial and meta-industrial workers. For this to happen, a new generation of political ecologists and militant scholars will need to take up the challenge of rethinking the working classes and their ecological agency.

\section{Acknowledgements}

Research for this article has been supported by the Czech Science Foundation under the project VEENEX: (GA ČR no. 16-17978S). I wish to thank Catia Gregoratti, Emanuele Leonardi, Irina Velicu, and three anonymous reviewers for their generous help in the writing process.

\section{References}

Arruzza, C., 2016. Functionalist, determinist, reductionist: social reproduction feminism and its critics. Sci. Soc. 80 (1), 9-30.

Barca, S., 2012a. Bread and poison. The story of labor environmentalism in Italy, 1968-1998. In: Melling, J., Sellers, C. (Eds.), Dangerous Trade. Histories of Industrial Hazards across a Globalizing World, Temple University Press.

Barca, S., 2014a. Laboring the Earth. Transnational reflections on the environmental history of work. Environ. History 19 (1), 3-27.

Barca, S., 2014b. 'Work, bodies, militancy: the "class ecology" debate in 1970s Italy'. In: Boudia, S., Jas, N. (Eds.), Powerless Science? Science and Politics in a Toxic World, Berghahn Books.

Barca, S., 2015. Greening the job. Trade unions, climate change and the political ecology of labour. In: Bryant, R. (Ed.), International Handbook of Political Ecology, London: Edward Elgar.

Bauhardt, C., 2014. Solutions to the crisis? The green newdeal, degrowth, and the solidarity economy: alternatives to the capitalist growth economy from an ecofeminist economics perspective. Ecol. Econom. 102, 60-68.

Burgmann, V., 2013. From ‘jobs versus environment' to 'green-collar jobs': Australian trade unions and the climate change debate. In: Räthzel, N., Uzzell, D. (Eds.), Trade Unions in the Green Economy. Routledge pp 131-145.

Burkett, P., 1999. Marx and Nature: A Red and Green Perspective. St. Martin's, New York.

Clark, B., 2001. Marx's natures: a response to foster and Burkett. Organ. Environ. 14 (4), 432-442.

Clarck, B., York, R., 2005. Carbon metabolism: global capitalism, climate change, and the biospheric rift. Theory Soc. 34 (4), 391-428.

Cock, J., 2014. The "Green Economy": a just and sustainable development path or a "Wolf in Sheep's Clothing"? Glob. Labour J. 5 (1), 23-44.

Conti, L., 1977, Che cos'è l'ecologia. Capitale, lavoro, ambiente [What is Ecology. Capital, Labour, Environment], Mazzotta.

D’Alisa, G., Demaria, F., Kallis, G., 2014. Degrowth. A vocabulary for a new era, Routledge.

Dalla Costa, M.R., 2003. The native in us, the Earth we belong to', The Commoner, n. 6, available at: < www.thecommoner.org >

Dalla Costa, M.R., 2015. Introduction to the Archive of Feminist Struggle for wages for housework', Viewpoint Magazine, issue 5, October, available at $<$ https:// viewpointmag.com/2015/11/02/issue-5-social-reproduction/ >

Della Porta, D., Diani, M., 2004. Movimenti senza protesta? L'ambientalismo in Italia [Movements without Protest? Environmentalism in Italy], Il Mulino.

Della Seta, R., 2000. La difesa dell'ambiente in Italia [The defence of the environment in Italy], Franco Angeli.

Ely, G., Nield, K., 2000. Farewell to the Working Class? Int. Labor Working-Class History $57,1-30$

Ely, G., 2002. Forging Democracy. The History of the Left in Europe, 1850-2000. Oxford University Press.

ETUC (European Trade Unions Confederation), 2015. Action Programme 2015-1019. available at. $<$ www.etuc.org $>$.

Federici, S., 2012. Revolution at Point Zero. Housework, Reproduction, and Feminist Struggle, PM Press.

Felli, R., 2014. An alternative socio-ecological strategy? International trade unions'

\footnotetext{
${ }^{13}$ See In defence of degrowth, cit., p. 14.
}

engagement with climate change. Rev. Int. Polit. Econ. 21 (2), 372-398.

Foster, J.B., 2000. Marx's Ecology. Materialism and Nature. Monthly Review Press, New York.

Foster, J.B., 2017. The Meaning of Work in a Sustainable Society: A Marxian View, CUSP Essay Series on the Morality of Sustainable Prosperity No 3. Available at: < http:// www.cusp.ac.uk/essay/m1-3/> .

Foster, J.B., Clark, B., 2016. Marx's ecology and the left. New Left Rev. 68. https:// monthlyreview.org/2016/06/01/marxs-ecology-and-the-left/.

Foster, J.B., Clark, B., York, R., 2010. The Ecological Rift: Capitalism's War on the Earth. Monthly Review Press, New York.

Fraser, N., 2014. Behind Marx's Hidden Abode. For an Expanded Conception of Capitalism, New Left Review, vol. 86, Mar-Apr, pp. 55-72.

Gaard, G., 2011. Ecofeminism revisited: rejecting essentialism and re-placing species in a material feminist environmentalism. Feminist Form. 23 (2), 26-53.

Gil, B.M., 2013. Moving towards eco-unionism: reflecting the Spanish experience. In: Räthzel, N., Uzzell, D. (Eds.), Trade Unions in the Green Economy. Routledge pp. 64-77.

Gingrich, S., 2013. From blue to green: a comparative study of blue-collar unions' reactions to the climate change threat in the United States and Sweden. In: Räthzel, N., Uzzell, D. (Eds.), Trade Unions in the Green Economy. Routledge pp. 214-226.

Goodman, J., Salleh, A., 2014. The 'Green Economy': class hegemony and counter-hegemony. Globalizations 10 (3), 411-424.

Gorz, A., 1979. Ecology and freedom. In: A. Gorz, Ecology as Politics, South End Press [1977, Écologie et liberté, Galilée].

Gorz, A., 1982. Farewell to the Working Class. An Essay on Post-Industrial Socialism, Pluto Press [1980, Adieux au Prolétariat, Galilée].

Gorz, A., 1989. Critique of Economic Reason, Verso [1988, Métamorphoses du travail, Galilée].

Gorz, A., 1999. Critique of economic reason: summary for trade unionists and other left activists. In: Munck, R., Waterman, P. (Eds), Labour Worldwide in the Era of Globalization. Alternative Union Models in the New World Order, Palgrave Macmillan.

Gorz, A., 2010, Ecologica, Seagull.

Graf von Hardenberg, W., Pelizzari, P., 2008. The environmental question, employment and development in Italy's left. Left History 2, 77-104.

Guha, R., Martínez Alier, J., 1997. Varieties of Environmentalism: Essays North and South, Earthscan.

Harvey, D., 1996. Justice, Nature and the Geography of Difference, Blackwell.

Kaika, M., 2017. 'Don’t call me resilient again!': the New Urban Agenda as immunology Ellipsis or Ellipsis what happens when communities refuse to be vaccinated with 'smart cities' and indicators. Environ. Urban. 29 (1), 89-102.

Leonardi, E., 2015. Introduzione. In: Gorz, A. (Ed.), Ecologia e libertà, Orthotes.

Luke, T.W., 2011. Environmentality. In: Dryzek, John S., Norgaard, Richard B., Schlosberg, David (Eds.), The Oxford Handbook of Climate Change and Society.

Martínez Alier, J., 2002. The Environmentalism of the Poor. A Study of Ecological Conflicts and Valuation, Cheltenham, UK: Edward Elgar.

Merchant, C., 2005. Radical Ecology. In: Search for a Livable World, 2nd ed. Routledge. Mellor, M., 1999. Feminism and Ecology, New York University Press.

Mellor, M., 2006. Ecofeminist political economy. Int. J. Green Econ. 1 (1/2), 139-150.

Mies, M., Bennholdt-Thomsen, V., 2000. The subsistence Perspective, Zed Books.

Mies, M., Shiva, V., 1993. Ecofeminism, Zed Books.

Mies, M., 1996. Patriarchy and Accumulation on the World Scale. Zed Books.

Mies, M., 2006. Questioning needs: a rejoinder to victor wallis. Capitalism Nat. Socialism 17 (4), 44-47.

Moore, J.W., 2011. Ecology, capital, and the nature of our times: accumulation \& crisis in the capitalist world-ecology. J. World-Systems Res. XVII (1), 108-147.

Murillo, L., 2013. From sustainable development to a green and fair economy: making the environment a trade union issue. In: Räthzel, N., Uzzell, D. (Eds.), Trade Unions in the Green Economy. Routledge pp. 29-40.

Perkins, P.E., 2007. Feminist ecological economics and sustainability. J. Bioecon. 9, $227-244$.

Räthzel, N., Uzzell, D., 2013. Mending the breach between labor and nature: a case for environmental labor studies. In: Räthzel, N., Uzzell, D. (Eds.), Trade Unions in the Green Economy. Routledge pp. 1-12.

Rootes, C., 2003. Environmental Protest in Western Europe. Oxford University Press.

Ryle, M., Soper, K., 2016. Introduction: the ecology of labour. Green Lett., 20(2), 119-126.

Salleh, A., 1997. Ecofeminism as Politics: Nature, Marx and the Post-Modern. Zed Books, London.

Salleh, A., 2006. CNS symposium: ecofeminist dialogues. Capitalism Nature Socialism 17 (4), 32-141.

Salleh, A., 2010. From metabolic rift to "Metabolic Value": reflections on environmental sociology and the alternative globalization movement. Organ. Environ. 23 (2), 205-219.

Salleh, A., 2012. "Green Economy" or Green Utopia: the salience of reproductive labor Post-Rio + 20. J. World-System Res. 18 (2), 138-145.

Silver, B.J., 2003. Forces of Labor. Workers' Movements and Globalization Since 1870. Cambridge University Press.

Snell, D., Fairbrother, P., 2013. Just transition and labour environmentalism in Australia. In: Räthzel, N., Uzzell, D. (Eds.), Trade Unions in the Green Economy. Routledge pp. $146-161$.

Soper, K., 1995. Feminism and ecology: realism and rhetoric in the discourses of nature. Sci. Technol. Human Values 20 (3), 311-331.

Stevis, D., 2013. Green jobs? Good jobs? Just jobs? US labour unions confront climate change. In: Räthzel, N., Uzzell, D. (Eds.), Trade Unions in the Green Economy. Routledge pp. 179-195. 
Sweeney, P., 2013. US trade unions and the challenge of "extreme energy": the case of the TransCanada Keystone XL pipeline. In: Räthzel, N., Uzzell, D. (Eds.), Trade Unions in the Green Economy. Routledge pp. 196-213.

Van der Linden, M., 2008. Workers of the World. Essays toward a Global Labor History, Brill.
White, D., Rudy, A., Gareau, B, 2016. Environments, Natures and Social Theory. Towards a Critical Hybridity, Macmillan Education UK.

Williams, R., 1984, 'Ecology \& the Labour Movement'. A talk given at the Plinston Hall,

Letchworth, 2nd June 1984. Available at: < https://www.youtube.com/watch?v $=$ EiFWHtKOcj0 $>$. 